Article

\title{
The Role of Vegetation in Climate Adaptability: Case Studies of Lodz and Warsaw
}

\author{
Małgorzata Hanzl ${ }^{1, *}$, Anna Tofiluk ${ }^{2}$, Kinga Zinowiec-Cieplik ${ }^{2}$, Magdalena Grochulska-Salak ${ }^{2}$ \\ and Anna Nowak ${ }^{2}$ \\ ${ }^{1}$ Faculty of Civil Engineering, Architecture and Environmental Engineering, Lodz University of Technology, Poland; \\ E-Mail: malgorzata.hanzl@p.lodz.pl \\ ${ }^{2}$ Faculty of Architecture, Warsaw University of Technology, Poland; E-Mails: anna.tofiluk@pw.edu.pl (A.T.), \\ kinga.cieplik@pw.edu.pl (K.Z.-C.), magdalena.salak@pw.edu.pl (M.G.-S.), anna.nowak@pw.edu.pl (A.N.) \\ * Corresponding author
}

Submitted: 10 May 2021 | Accepted: 24 June 2021 | Published: 14 October 2021

\begin{abstract}
The threats that arise from climate change and their associated economic, social, and environmental impacts are leading to the transformation of the spatial structures of cities. The growing demand for climate adaptability calls for the development of normative criteria for the design of forms of urban settings that integrate vegetation. Climate-responsive urban design reacts to the challenges of urban physics, which depend heavily on the forms of urban structures and the role of greenery. This method includes research on vegetation indexes and their impact on urban regulatory functions. The goal is to propose a comprehensive framework for assessing the functioning of urban public space, which considers the role and maintenance of green infrastructure. The intersection with the subject matter of analytical urban morphology is evident, in terms of the resolution of the urban fabric and its transformations over time. The framework of climate-responsive urban design also covers examining the parameters of surrounding built structures, such as the floor area ratio, the building coverage ratio, and building heights. In particular, the requirements of climate adaptation have an impact on the design of outdoor spaces in cities. In this article, we apply the selected methods that contribute to the climate-responsive urban design model to recommend the transformations of two urban nodes, in Lodz and Warsaw (Poland). Our goal is to indicate the future form of nodal public spaces with a focus on the needs of urban greenery, and to determine indicators for the local climate zone. After an initial literature review, we discuss a number of available indicators from the perspective of how they might contribute to determine the environmental conditions. We focus on urban water cycle, the requirement of trees for water, and insolation conditions.
\end{abstract}

\section{Keywords}

climate adaptability; ecosystem services; green infrastructure; Lodz; urban design; urban vegetation; Warsaw

\section{Issue}

This article is part of the issue "Towards Green(er) Cities: Contextualizing Green Benefits for Urban Spaces and Contemporary Societies" edited by Juaneé Cilliers (University of Technology Sydney, Australia).

(C) 2021 by the authors; licensee Cogitatio (Lisbon, Portugal). This article is licensed under a Creative Commons Attribution 4.0 International License (CC BY).

\section{Introduction}

Cities are complex social-ecological systems that engage numerous stakeholders and embrace diverse ecological processes (Alberti, 2008; Andersson et al., 2014; Berkes \& Folke, 2000). While the need for climate adaptation in cities has been broadly recognised (European
Commission, 2021; European Environment Agency, 2016; Mayor of London, 2018; Reusswig et al., 2016), there is still the question of how to engage concerned actors in the desired stewardship. We believe that improved understanding of regulatory ecosystem services would help address this issue. The three-fold nature of social-ecological systems in cities includes 
infrastructures, institutions, and perceptions (Andersson et al., 2019). In this article, we address the first of these elements, urban infrastructures, in the quest for a normative framework for design purposes. We further divide this category into so-called grey infrastructure (buildings, parcels, streets, and squares) and green infrastructure (Gl, various forms of vegetation; Marcus et al., 2019). The first group remains subject to urban morphology research (Caniggia \& Maffei, 2001; Conzen, 1960; Oliveira, 2016), and the second belongs to the scope of urban ecology (Alberti, 2008; Andersson, 2006; Colding et al., 2013; Forman \& Godron, 1986). Both the urban fabric and Gl impact the urban microclimate. Cities as man-made habitats are influenced by geographical factors, including both abiotic and biotic factors, but also the intensity and range of human activities.

The ecological processes in cities are not confined to a single ecosystem; instead, cities are a mosaic of interconnected ecosystems that interact. Spatial patterns affect them to the point that they can be assumed based on the distribution and structural configuration (Andersson, 2006). In addition to the mutual relationships and spatial links, the analysis should consider the panarchy of interconnected habitats, which embraces multiple scales. In urban cores, new interventions in woodlands usually belong to the category of "functional greening" with planted tree stands in green spaces (Kowarik, 2005, p. 9). Therefore, to design successful urban climate adaptation measures integrating vegetation, it is first necessary to understand the processes between the urban fabric and GI. Then, we should trace the relationships between the elements of $\mathrm{Gl}$ within the social-ecological urban system.

In this article, we analyse two urban spaces located in two major Polish cities: Warsaw and Lodz. We consider both the elements of their infrastructures and their interrelations. In the next section, we present the research background, followed by the methodology and the case study characteristics. We then apply the selected methods to both sites and discuss the results. The final section includes recommendations and proposes future research paths.

\section{Research Background}

Climate change adaptation has attracted much attention from researchers in recent years. Most research so far relates to evaluating ecosystem services on the scale of a region (Carter et al., 2015; Haase et al., 2012; Niemelä et al., 2010; Schirru et al., 2019) or a city (Gill et al., 2007; Liu \& Russo, 2021). There are fewer studies that address the scale of the neighbourhood. There are numerous reasons for this discrepancy. First of all, the natural conditions are challenging to parameterise, due to the many variables. The local conditions include, among others, topography, soil structure, climate, and anthropomorphic transformations, such as soil sealing and existing biodiversity. The plant forms range from simple lawns to complex systems of low vegetation, such as lawns, ground cover, perennials, and bulbous plants, from annuals and biennials to shrubs, tall trees, and creepers. All these elements are affected by their immediate and broader context. There are also few studies considering the relations between different types of infrastructure in a comprehensive manner. Most research that deals with interrelations between urban spaces and green areas addresses a single theme, such as urban heat island (UHI; Armson et al., 2012; Kannamma \& Sundaram, 2015; Norton et al., 2015; Shashua-Bar \& Hoffman, 2003). The urban or metropolitan context is evident in studies on the role of greenways as connecting elements for the growth and preservation of biodiversity (Alberti, 2008; Bryant, 2006). Other phenomena discussed above also need to be included in a system and panarchy approach.

In this article, we refer to the Millennium Ecosystem Assessment (2005), which provides a commonly recognised framework to evaluate the benefits of GI. GI contributes to the social-ecological system, the design of which needs to be comprehensively understood (Redman et al., 2004). The scheme includes four categories of ecosystem services: supporting, provisioning, regulating, and cultural. Climate change adaptation, which is the topic of this article, deals primarily with regulatory services, including, among others, water retention and UHI reduction. The concept of normative guidelines for designing urban settings and integrating vegetation has attracted the interest of researchers before (McDonald et al., 2007; Whitford et al., 2001). Climate-responsive urban design addresses the interplay of urban physics and ecosystem challenges, which depend on the forms of urban structures and the role of fauna and flora. Studies that merge these two topics are still rare. For example, Marcus et al. (2019) recommend a combined socio-ecological morphology. They propose two systems of overlapping patches representing social entities: built structures and ecological structures. We focus on the regulatory functions of urban ecosystems, which we attempt to link with some characteristics of built structures.

\section{Methodology}

The impact of vegetation on urban settings was assessed based on several factors. Each specific feature has its distinctive methodology of assessment defined in the subject literature. Table 1 presents the primary regulatory ecosystem functions associated with the characteristics of $\mathrm{Gl}$. The relationships defined in all three tables were defined based on the initial literature review, which led to the selection of a number of indicators that describe urban vegetation (Table 1), types of vegetation (Table 2), and forms of urban structures (Table 3). For each of these elements, we determined how they affect local environmental conditions. The focus of the current article is on developing proper conditions for 
Table 1. Parameters of urban vegetation in relation to the role of greenery as a factor affecting comfort and climate adaptability.

\begin{tabular}{|c|c|c|c|c|c|c|c|c|}
\hline \multirow{2}{*}{\multicolumn{2}{|c|}{ Ecosystem Services }} & \multicolumn{7}{|c|}{ Parameter Describing Urban Vegetation } \\
\hline & & \multirow{2}{*}{$\begin{array}{c}\begin{array}{c}\text { Leaf Area } \\
\text { Index }\end{array} \\
x^{1}\end{array}$} & \multirow{2}{*}{$\begin{array}{c}\text { Tree Canopy } \\
\text { Cover/Tree } \\
\text { Roots Extent }\end{array}$} & \multirow[t]{2}{*}{$\begin{array}{l}\text { Normalised } \\
\text { Retention/ } \\
\text { Infiltration } \\
\text { Index }\end{array}$} & \multirow[t]{2}{*}{$\begin{array}{l}\text { Difference } \\
\text { Vegetation } \\
\text { Index }\end{array}$} & \multirow[t]{2}{*}{$\begin{array}{l}\text { Carbon } \\
\text { Storage } \\
\text { Index }\end{array}$} & \multirow[t]{2}{*}{$\begin{array}{l}\text { Biological } \\
\text { Diversity } \\
\text { Index }\end{array}$} & \multirow[t]{2}{*}{$\begin{array}{l}\text { Indigenous } \\
\text { Species } \\
\text { Index }\end{array}$} \\
\hline 1. & Cooling of UHI & & & & & & & \\
\hline 2. & $\begin{array}{l}\text { Preventing water } \\
\text { cumulation during } \\
\text { flash floods }\end{array}$ & $x^{3}$ & $x$ & $x$ & $x^{4}$ & & & \\
\hline 3. & $\begin{array}{l}\text { Water retention } \\
\text { and infiltration: } \\
\text { draft prevention }\end{array}$ & $x^{5}$ & $x^{6}$ & $x^{6}$ & $x^{4}$ & & & \\
\hline 4. & $\begin{array}{l}\text { Strong wind } \\
\text { prevention }\end{array}$ & $x$ & $x$ & & & & & \\
\hline 5. & $\begin{array}{l}\text { Air pollution } \\
\text { prevention }\end{array}$ & $x^{7}$ & $x^{8}$ & & & & $x^{9}$ & \\
\hline 6. & Rainwater cleansing & $x$ & $x^{6}$ & $x$ & $x^{4}$ & & & \\
\hline 7. & $\begin{array}{l}\text { Soil pollution } \\
\text { prevention }\end{array}$ & $x^{10}$ & $x^{11}$ & & $x$ & & $x^{9}$ & \\
\hline 8. & $\begin{array}{l}\text { Prevention of } \\
\text { organic pollutants } \\
\text { and bacteria }\end{array}$ & $x^{12}$ & $x^{13}$ & & & & & \\
\hline 9. & $\begin{array}{l}\text { Urban vegetation } \\
\text { resilience, adjustment } \\
\text { to urban conditions }\end{array}$ & $X^{14}$ & $x^{15}$ & $x^{16}$ & $x$ & $x$ & $X^{9}$ & $x^{17}$ \\
\hline
\end{tabular}

Notes: ${ }^{1}$ Pace et al. (2021); ${ }^{2}$ Köhler and Kaiser (2019); Loughner et al. (2012); Ziter et al. (2019); ${ }^{3}$ Jalolen et al. (2013); Yang et al. (2019); ${ }^{4}$ Szczepanowska and Sitarski (2015); ${ }^{5}$ Simic et al. (2004); Yang et al. (2019); ${ }^{6}$ Law and Hanson (2016); Janhäll, (2015); ${ }^{8}$ Badach et al. (2020); Barwise and Kumar (2020); Nowak (2002); ${ }^{9}$ Gaj (2012); Nowak et al. (2013); ${ }^{10}$ Nascimento et al. (2016); ${ }^{11}$ Pérez-Suárez et al. (2008); ${ }^{12}$ Wei et al. (2017); ${ }^{13}$ Gong et al. (2021); Nakamura et al. (2017); ${ }^{14}$ Wu and Liang (2020); ${ }^{15}$ Hale et al. (2015); ${ }^{16}$ Gustafsson et al. (2020); ${ }^{17}$ Oliver et al. (2015); Rowntree and Nowak (1991).

urban greening interventions to achieve the highest performance in terms of ecosystem regulatory functions.

Table 2 relates types of urban vegetation to their regulatory ecosystem functions. The roles of various types of vegetation differ. To successfully design urban spaces, we should be able to take this into account. Table 3 shows the impacts of urban forms on the local environment, including vegetation. These aspects are rarely considered in urban ecosystem research. However, the analysis of the potential impact of various features of urban structures on the physical conditions of urban space proves their essential role.

Based on the above analyses, we selected those features of the urban environment which are essential for shaping climate adaptability. In the following sections, we discuss some of the aspects of the parameters listed above, which we will then use in the case study analysis.

\subsection{Biodiversity}

Designers usually understand biodiversity as species diversity, which translates into a variety of taxonomic units. In ecological research it is not always a positive parameter, because of the likely presence of alien and invasive species which, in turn, can only be assessed in the context of a given place. For example, suppose native species in a given place have challenging conditions for vegetation due to anthropogenic transformations, and foreign and even invasive species cope in this place. In such cases, the negative assessment of invasive taxa will not be unambiguous. Moreover, biodiversity research emphasises the potential for the emergence of spontaneous vegetation. It involves the openness of the designed compositions to the "adoption" of new species and natural processes. The species composition translates into the provided and expected ecosystem services. For example, some plants have phytoremediation abilities (Piotrowska-Niczyporuk \& Bajguz, 2013). Studies on the capture of particulate matter by trees in cities show that linden can be one of the most efficient species in this respect (Popek, 2013).

Research on biodiversity uses various, often very complex methods (Kruk, 2014), which are challenging in everyday design practise due to the time required to observe the directions of changes (at least one growing season, and preferably in long-term studies). In addition, 
biodiversity can be considered at the level of the diversity of taxonomic units (as above), at the level of the gene pool, or, finally, at the scale of entire ecosystems (the latter requires time, a large team, and specialised equip- ment). Researchers agree that conducting analyses using only one of the methods cannot yield reliable results. The biodiversity taxonomy parameter seems to be the easiest to use in design.

Table 2. Types of vegetation and their role in climate adaptation: + (influence) , + - (relative influence), and - (no influence).

\begin{tabular}{|c|c|c|c|c|c|c|c|}
\hline \multirow[b]{3}{*}{ Role } & \multicolumn{7}{|c|}{ Types of Vegetation } \\
\hline & \multicolumn{2}{|c|}{ Trees } & \multicolumn{2}{|c|}{ Bushes } & \multirow{2}{*}{$\begin{array}{l}\text { Climbers } \\
\text { and } \\
\text { Ground } \\
\text { Covers }\end{array}$} & \multirow{2}{*}{$\begin{array}{l}\text { Perennials } \\
\text { and } \\
\text { Herbaceous } \\
\text { Plants }\end{array}$} & \multirow[t]{2}{*}{ Grasses } \\
\hline & Deciduous & Coniferous & Deciduous & Coniferous & & & \\
\hline \multicolumn{8}{|l|}{ Temperature regulation: } \\
\hline 1. Cooling of UHI ${ }^{1}$ & + & $+1-$ & + & $+1-$ & + & $+1-$ & $+1-$ \\
\hline 2. Warming in cold seasons ${ }^{2}$ & - & + & - & + & $+1-$ & - & - \\
\hline $\begin{array}{l}\text { 3. Resilience to temperature } \\
\text { amplitudes and abrupt } \\
\text { changes }^{1}\end{array}$ & $+1-$ & + & $+1-$ & + & $+1-$ & $+1-$ & - \\
\hline \multicolumn{8}{|l|}{ Water regulation: } \\
\hline $\begin{array}{l}\text { 4. Preventing water runoff } \\
\text { and flooding during } \\
\text { flash floods }{ }^{3}\end{array}$ & $+/-$ & $+1-$ & $+1-$ & $+1-$ & $+1-$ & + & + \\
\hline $\begin{array}{l}\text { 5. Water retention } \\
\text { and infiltration: } \\
\text { draft prevention } 4\end{array}$ & + & $+1-$ & + & $+1-$ & $+1-$ & + & $+1-$ \\
\hline $\begin{array}{l}\text { 6. Rainwater cleansing, soil } \\
\text { pollution prevention }{ }^{5}\end{array}$ & + & $+1-$ & + & $+1-$ & + & + & - \\
\hline \multicolumn{8}{|l|}{ Air flow regulation ${ }^{6}$ : } \\
\hline 7. Strong wind prevention & + & + & + & + & $+1-$ & - & $+1-$ \\
\hline 8. Air pollution prevention ${ }^{7}$ & + & $+1-$ & + & $+1-$ & + & $+1-$ & $+1-$ \\
\hline \multicolumn{8}{|l|}{ Others: } \\
\hline $\begin{array}{l}\text { 9. Prevention of organic } \\
\text { pollutants and bacteria: } \\
\text { etheric substances }{ }^{8}\end{array}$ & $+1-$ & + & $+1-$ & + & - & $+1-$ & - \\
\hline $\begin{array}{l}\text { 10. Urban vegetation } \\
\text { resilience, adjustment } \\
\text { to urban conditions }{ }^{9}\end{array}$ & + & $+1-$ & + & $+1-$ & + & + & $+1-$ \\
\hline
\end{tabular}

Notes: ${ }^{1}$ Norton et al. (2015); Szczepanowska and Sitarski (2015); ${ }^{2}$ Myint et al. (2015); ${ }^{3}$ Jalolen et al. (2013); ${ }^{4}$ Simic et al. (2004); Yang et al. (2019); ${ }^{5}$ Dierkes et al. (2002); Szczepanowska and Sitarski (2015); ${ }^{6}$ Chen et al. (2016); ${ }^{7}$ Badach et al. (2020); Barwise and Kumar (2020); Janhäll (2015); Nowak (2002); Szczepanowska and Sitarski (2015); ${ }^{8}$ Gong et al. (2021); Nakamura et al. (2017); Wei et al. (2017); ${ }^{9}$ Gustafsson et al. (2020); Hale et al. (2015); Oliver et al. (2015); Szczepanowska and Sitarski (2015); Wu and Liang (2020).

Table 3. Features of the physical environment and their role in climate adaptation.

\begin{tabular}{|c|c|c|c|c|c|c|}
\hline \multirow[b]{2}{*}{ Role } & \multicolumn{6}{|c|}{ Features of Physical Environment } \\
\hline & $\begin{array}{c}\text { Floor Area } \\
\text { Ratio/Building } \\
\text { Coverage } \\
\text { Ratio }\end{array}$ & $\begin{array}{l}\text { Height of } \\
\text { Buildings }\end{array}$ & $\begin{array}{l}\text { Direction } \\
\text { vs. Wind } \\
\text { Direction }\end{array}$ & $\begin{array}{l}\text { Setback/ } \\
\text { Location } \\
\text { on the Lot }\end{array}$ & $\begin{array}{l}\text { Floor } \\
\text { Materials } \\
\text { and } \\
\text { Colours }\end{array}$ & $\begin{array}{c}\text { Colours of } \\
\text { Facades }\end{array}$ \\
\hline Temperature regulation & $x$ & $x$ & $x$ & $x$ & $\mathrm{X}$ & $x$ \\
\hline Water regulation & $x$ & & $\mathrm{X}$ & $x$ & $\mathrm{X}$ & \\
\hline Air flow regulation & $x$ & $x$ & $x$ & $x$ & & \\
\hline Urban vegetation resilience & $x$ & $x$ & $x$ & $x$ & $x$ & \\
\hline Physical conditions for social activities & $\mathrm{X}$ & $X$ & $\mathrm{X}$ & $x$ & $X$ & $X$ \\
\hline
\end{tabular}




\subsection{Carbon Sequestration}

Species diversity is not the only parameter. Other features include natural efficiency, i.e., how much oxygen vegetation gives off to the atmosphere and how much it sequesters and builds into carbon tissues (Nowak et al., 2013), and how the area evapotranspires, which translates into microclimatic conditions. It should be noted that increased biodiversity does not equal higher biomass production nor higher $\mathrm{CO}_{2}$ sequestration (Köhler \& Kaiser, 2021; Körner, 2000).

Individual tree species, in various development stages and depending on the growing season (varying leaf sizes), have different effects in the form of coefficients. These can be calculated based on so-called allometric equations of biomass for individual species (Zasada et al., 2008), which vary depending on the species, its geolocation, neighbourhood conditions, etc. (Altanzagas et al., 2019). Zianis et al. (2005) show the extent of the problem, pointing to 188 trees of one species of Pinus silvestris with over 50 different patterns. Therefore, it would be necessary for design purposes to average the data for individual species in a given city. Such compilations have been made in the US (Peper et al., 2007). In Poland, pioneering research in this area was conducted by Szczepanowska and Sitarski (2015). Analyses of street trees in Praga Północ show (resulting from American research by, among others, Nowak et al., 1996; Nowak et al., 2013; Peper et al., 2007) a hypothetical sequestration efficiency in the range of between $81 \mathrm{~kg} \mathrm{CO}_{2} /$ mature tree/year and $7 \mathrm{~kg} \mathrm{CO} /$ small tree/year, where an average of $25 \mathrm{~kg} \mathrm{CO}_{2} /$ tree/year was assumed. We calculated the amount of sequestrated $\mathrm{CO}_{2}$ using the equation: $\mathrm{W}_{\mathrm{CO}_{2}}=n \times 25 \mathrm{~kg} /$ year, where $\mathrm{n}$ is the number of trees
and $\mathrm{W}_{\mathrm{CO}_{2}}$ is the amount of sequestered $\mathrm{CO}_{2}$

Knowing the level of $\mathrm{CO}_{2}$ sequestration, it is possible to calculate the amount of $\mathrm{O}_{2}$ produced by trees using the formula $\mathrm{W}_{\mathrm{O}_{2}}[\mathrm{~kg} /$ year $]=\mathrm{W}_{\mathrm{CO}_{2}}[\mathrm{~kg} /$ year $] \times 32 / 12$ (Nowak et al., 2007).

\subsection{Normalised Difference Vegetation Index}

Another important index is the normalised difference vegetation index (NDVI), which determines the intensity of photosynthesis. NDVI maps are created by municipalities and can provide information about the health of vegetation.

\subsection{Rainwater Retention}

Rainwater retention is an essential feature for landscaping. Watering using a balance of local water retention and water supplies is desired. We based the calculations on the formula:

$$
Q_{r}=r_{t ; n} \times \Psi_{m} \times \Sigma A
$$

where $Q_{r}$ is the surface runoff, $r_{t ; n}$ is the design rain value, $\Psi_{m}$ is the runoff coefficient- $\left(\Psi_{1} \times A_{1}+\Psi_{2} \times A_{2}+\right.$ $\left.\cdots+\Psi_{n} \times A_{n}\right) / \Sigma A-$ and $\Sigma A$ represents the total surface$\Sigma A=A_{1}+A_{2}+A_{n}$. This was based on works by Dreiseitl and Grau (2009), Geiger and Dreiseitl (1999), and Geiger et al. (2010). The following values were adopted for the calculations:

- Design rainfall: $177.1 \mathrm{l} / \mathrm{s}$ (for 15 minutes of rain every five years; RetencjaPL, 2020);

- Runoff coefficients (Geiger \& Dreiseitl, 1999): For impermeable surfaces $\Psi_{1}=0.90$, for gravel surfaces $\Psi_{2}=0.15$, and for surfaces covered with greenery $\Psi_{3}=0.05$.

\subsection{Watering Demands}

According to contemporary water management standards, retention should support the irrigation of growing plants (Moser et al., 2017). The water demands of plants depend on many factors: plant size, season (including temperature, leaf size), plant species, and climatic or local conditions. Irrigation requirements can be calculated based on the evapotranspiration index, using the principle that evaporated water should be replaced through irrigation. The most popular models are the four models of the ETo index: a model based solely on temperature measurements; Garbarczyk's model based on air temperature and humidity measurements; the Hargreaves model, calculated based on temperature and latitude; and the Penaman-Monteith model, calculated based on temperature, altitude, air humidity, radiation, and wind speed. All these models were developed for production plants, including fruit trees. The frequency of watering is also important. The best growth conditions are achieved by water-spraying trees, which means less frequent (once a week or less) but more abundant watering. Bartosiewicz (1986) recommends periods of 20-40 days between watering trees and giving a single dose of $50-100 \mathrm{l} / \mathrm{m}^{2}$ under the canopy of trees, assuming a depth of 30-60 cm. On the other hand, Borowski et al. (2016) do not distinguish between the amount of water required for watering trees. They only discuss watering a layer of $35 \mathrm{~cm}$ of soil for deeper-rooting plants and give the value of $35 \mathrm{I}$ of water per $\mathrm{m}^{2}$ of the area under the tree canopy or the vegetated surface for other plants. For trees, we can also calculate the amount of water using the breast height diameter (DBH). This method assumes a conversion factor whereby one centimetre of trunk diameter equals 10 I of water per every 20-40 days (Bartosiewicz, 1986).

\subsection{Insolation Analyses}

Insolation analyses should begin at the concept stage of design proposals (Saratsis et al., 2017). Sunlight studies in the urban context focus mainly on proper daylight illumination of rooms. Good insolation is vital for the energy 
efficiency of a facility, the possibility of supporting natural ventilation, or obtaining solar energy (Hegger et al., 2008). The arrangement of a building can have an effect on indoor insolation (Fernandez et al., 2015). Outdoor conditions have so far received less attention. The outdoor environment can contribute to providing sufficient ventilation and preventing heat island. Insolation should be considered when deciding the location of renewable energy sources. It is also essential for public space design, in terms both of its social aspects and green and blue infrastructure requirements. In the following section, we focus on the impact of insolation on vegetation growth conditions.

\section{Case Studies}

The need to adapt to climate change is now widely recognised among scientists, politicians, and municipal decision-makers (e.g., City of Paris, 2018; European Commission, 2021; European Environment Agency, 2016; Kassenberg et al., 2019; Mayor of London, 2018; Reusswig et al., 2016). However, in many cities, including Polish ones, the implementation of measures aimed at tackling climate change has not started or is not advanced. Urban adaptation plans have been elaborated for 44 major Polish cities, but the transformation of the urban fabric, taking into account the consequences of climate change, has not gained momentum. We attribute this situation to the lack of well-established methods for adapting the built environment to new conditions, despite many studies that provide adaptation guidelines (e.g., Crichton et al., 2009; Filho, 2015; Jones, 2017; Košir, 2019; Naumann et al., 2020). First, every local situation is different. Cities differ in their latitude and climatic conditions (Stewart \& Oke, 2012), which has consequences for the choice of adaptation measures. Moreover, for each site, adaptation strategies must respond to the local conditions and, above all, cater to the demands of the local community. At the same time, they should harmoniously fit into the surrounding urban fabric and the local system of ecological connections. Adaptive transformations relate to several design levels, from the regional and city level (spatial and urban planning) to the neighbourhood scale (urban design), and from spatially separated parts of districts (housing estates, urban blocks) to the scale of a single building.

To verify the assumed methodology and formulate adaptation recommendations, we selected two sites: Grzybowski Square, in Warsaw, and the Old Market, in Lodz. We analyse these two public spaces against the backdrop of surrounding neighbourhoods. We pay special attention to the relations between the urban vegetation and the adjacent system of urban greenery. Both sites are centrally located and both used to work as urban nodes in the past. Moreover, both contain a certain amount of vegetation and are connected to neighbouring GI (Figure 1). Both Warsaw and Lodz have strategic documents defining the directions of adaptation (City of Lodz, 2018; Kassenberg et al., 2019). However, they are awaiting more specific guidelines.

\subsection{Grzybowski Square, Warsaw}

Grzybowski Square was the market square of Grzybów "jurydyka," established in 1650 and incorporated into the capital at the end of the 18th century. It owes its triangular shape to its location at the intersection of transportation routes. Initially surrounded by one- or two-storey wooden buildings, from 1820 its facades were gradually replaced with five-floor masonry tenement houses.

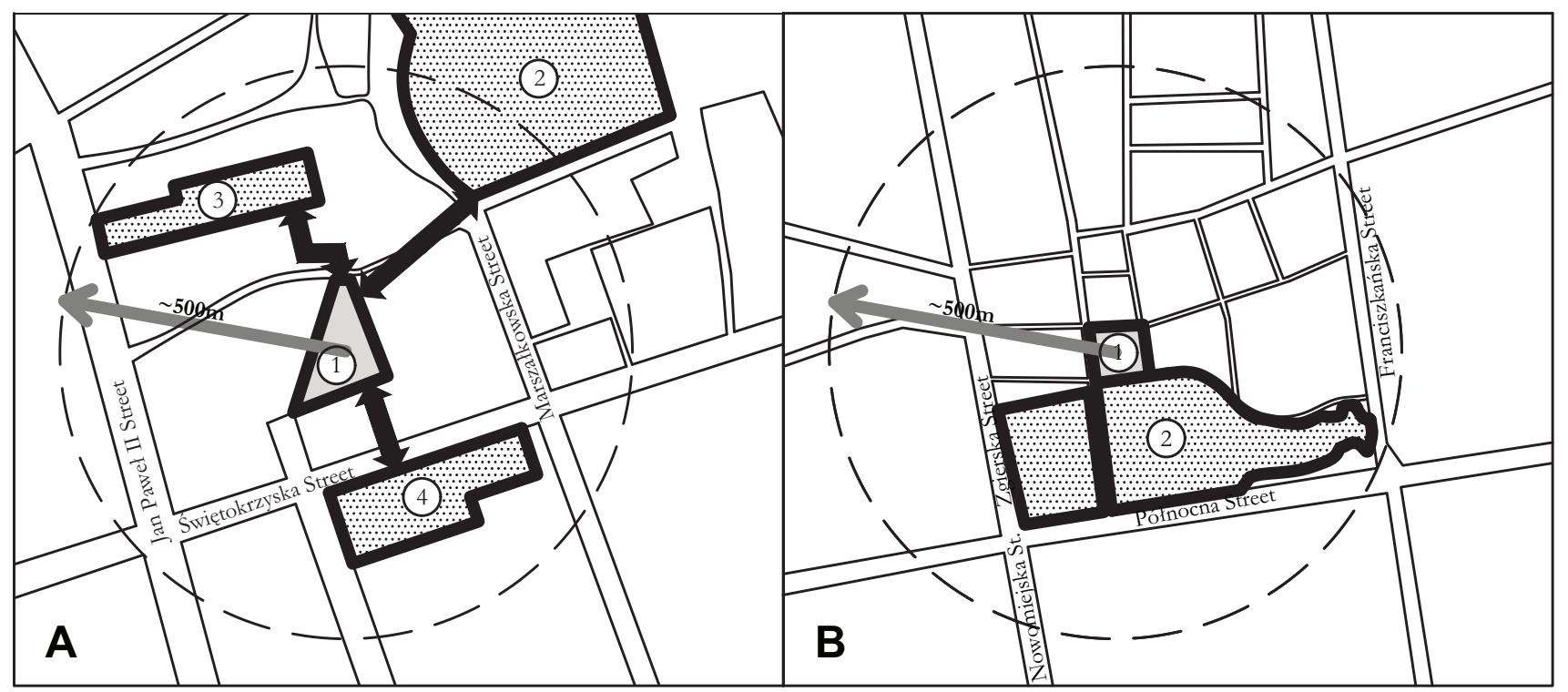

Figure 1. A) Location of city parks in the vicinity of Grzybowski Square (within $0.5 \mathrm{~km}$ ): 1. Grzybowski Square, 2. Ogród Saski (The Saxon Garden), 3. Park Mirowski (Mirowski Park), 4. Park Świętokrzyski (Świętokrzyski Park); B) Location of city parks in the vicinity of Old Market Square (within $0.5 \mathrm{~km}$ ): 1. Old Market Square, 2. Park Staromiejski (Staromiejski Park). 
The prominent landmark, All Saints' Church, was erected between 1861 and 1879. During the Second World War, the square became part of the Jewish ghetto. Only a few buildings from before 1939 have survived; others were destroyed during wartime or later replaced with housing estates. The post-war residential towers were higher (13 floors) and did not strictly follow the historical layout (Figure 2A). The current development of the square (Figure 2B) also includes office and service buildings since 1989, including the Cosmopolitan skyscraper (2014). A new high-rise to replace the Jewish Theatre demolished in 2017 could reach the height of the nearby skyscraper, according to visualisations made available by the investor.

From the mid-17th to almost the end of the 19th century, the square was a place of trade. Until 1820 it was unpaved. In 1897, with the completion of the main church construction works, it was decided to remove the market. The square was partially de-paved, and a fenced green area was created. Trees were planted both on the green space and along the frontage. After the war, the square and the entire area was neglected for many years. In 1969, the modernisation of the interior of the square began.

As a result, paths cutting across the pre-war green area were created, and the avenue which was to lead on its extensions to the Saski Garden and Świętokrzyski Park was emphasised with tree rows (Figure 2A). In this way, it was planned to link the greenery of the square with the broader system of urban greenery. In 2007, the artist Joanna Rajkowska created an installation-the oxygenator-in the square. This inspired a competition to modernise the square. The new solution limited and arranged parking, reorganised the traffic rules, and rearranged the greenery of the square and its other elements (Figure 2B). The green area decreased. Table 4

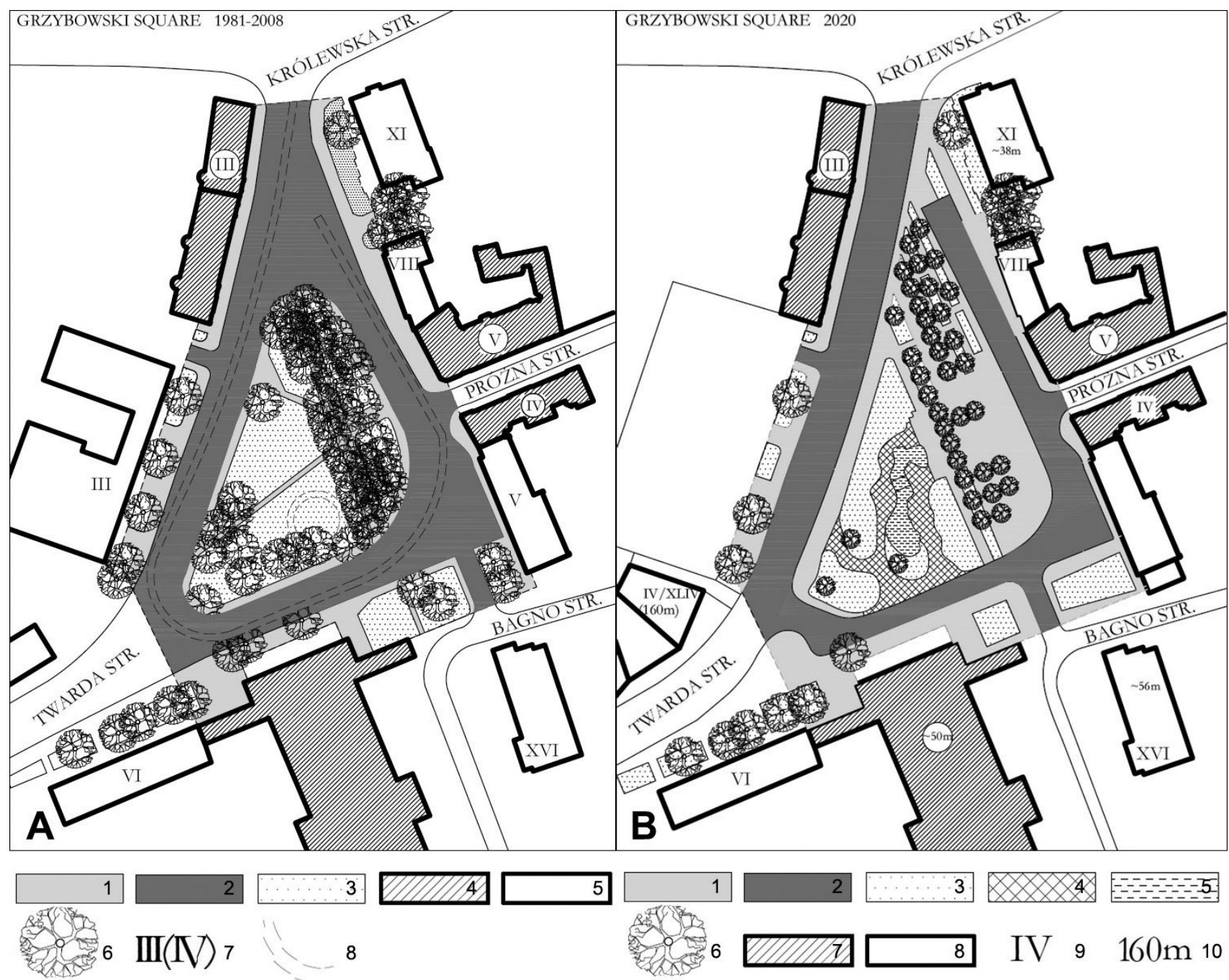

Figure 2. Grzybowski Square. A) 1981-2008. Legend: 1. Pavement/concrete slabs, 2. Roadways and parking (tarmac), 3. Lawns, 4. Pre-war buildings, 5. Buildings since 1945, 6. Trees, 7. Number of floors (overbuilt), 8. Oxygenerator 2007, and 9. Unused tramway tracks; B) 2020. Legend: 1. Pavement, 2. Roadways and parking (tarmac), 3. Lawns, 4. Permeable surface, 5 . Water surface, 6 . Trees, 7. Pre-war buildings, 8. Buildings since 1945, 9. Number of floors, and 10. Maximum building height. 
Table 4. Grzybowski Square, Warsaw: Percentage share of different surfaces in the area of the square.

\begin{tabular}{|c|c|c|c|c|c|}
\hline & & End of the 19th Century & 1900-1939 & 1981-2008 & 2020 \\
\hline Paved area: & Pedestrians & $100 \%\left(15,000 \mathrm{~m}^{2}\right)$ & $25 \%\left(3,800 \mathrm{~m}^{2}\right)$ & $27 \%\left(4,250 \mathrm{~m}^{2}\right)$ & $40 \%\left(6,300 \mathrm{~m}^{2}\right)$ \\
\hline Impervious surface & Traffic & & $36 \%\left(5,400 \mathrm{~m}^{2}\right)$ & $43 \%\left(6,600 \mathrm{~m}^{2}\right)$ & $33 \%\left(5,100 \mathrm{~m}^{2}\right)$ \\
\hline \multicolumn{3}{|l|}{ Permeable surfaces } & & & $5 \%\left(800 \mathrm{~m}^{2}\right)$ \\
\hline \multicolumn{3}{|c|}{ Biologically active surface } & $39 \%\left(5,800 \mathrm{~m}^{2}\right)$ & $30 \%\left(4,750 \mathrm{~m}^{2}\right)$ & $20 \%\left(3,100 \mathrm{~m}^{2}\right)$ \\
\hline \multicolumn{3}{|l|}{ Water surface } & & & $2 \%\left(300 \mathrm{~m}^{2}\right)$ \\
\hline
\end{tabular}

Notes: Permeable surface, other than biologically active surface, including "threshing floor." All values included in the table are approximate.

presents the share of different surfaces in the total surface of the square. These values were used in the further calculations.

\subsection{The Old Market, Lodz}

The Old Market dates back to when Lodz received city status in 1423 . The low wooden structures which surrounded the square were gradually replaced by masonry buildings (up to three floors high) in the 19th century. The buildings surrounding the square became dilapidated during the Second World War, when this site was included in the Jewish ghetto. In the post-war period the structures were replaced by housing estates and a newly created park from the south (Figure 3 ). The site lost its former role as a node of local life.

Until the middle of the 19th century, the surface of the square was entirely unpaved. In 1841 , paving of the road began, followed by two lanes of pavement crossing the square's surface, which ensured more efficient transport of goods to the stalls. In 1925, it was decided to transform the square into a town square. Trees and lawns appeared. After the war, the greenery in the central part was replaced by lawns with rows of trees along the frontage. The central part of the square was paved over. Currently, the municipality plans to modernise the

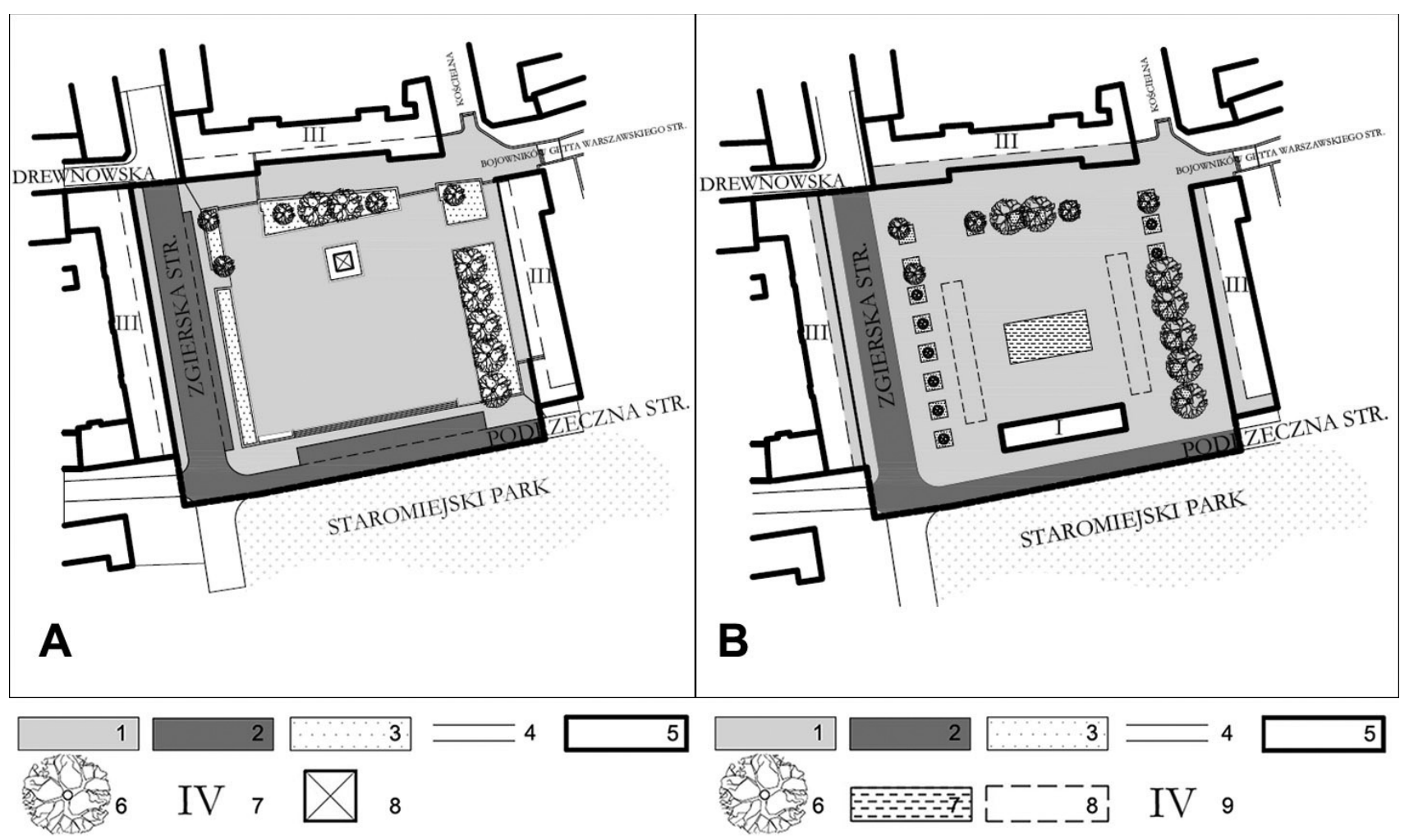

Figure 3. Old Market Square, Lodz. A) 1956-2021. Legend: 1. Pavement, 2. Roadways, 3. Lawns, 4. Trees, 5. Buildings, 6. Tramway tracks, 7. Number of floors, 8. Monument of Julian Marchlewski (1964-1989); B) Concept design of 2016 planned redevelopment, designed by Jakub Krzysztofik, Sylwia Krzysztofik, and Michał Domińczak. Legend: 1. Pavement, 2. Roadways, 3. Lawns, 4. Trees, 5. Buildings and new pavilion, 6. Tramway tracks, 7. Number of floors, 8. Light structures (canopies, design stalls), 9. Pavement fountain. 
square together with the neighbouring park. Trees are to remain on the square; the biologically active surface is to be reduced; and the pavement is to be replaced and complemented with new street furniture and a small pavilion on the park side. Table 5 presents the share of different surfaces in the total surface of the square. These values were used in further calculations.

\section{Results}

In the analysis, we focused on three connected aspects of the urban environment: surface runoff; the watering demands of trees; and the insolation of urban spaces.

\subsection{Calculation of Surface Runoff and Watering Demands}

For Grzybowski Square in Warsaw, surface runoff was calculated according to the above formulae where:

$A_{1}=6,300 \mathrm{~m}^{2}+5,100 \mathrm{~m}^{2}=11,400 \mathrm{~m}^{2}$;

$A_{2}=800 \mathrm{~m}^{2} ; A_{3}=3,100 \mathrm{~m}^{2}$

$\Psi_{1} \times A_{1}=0.90 \times 11,400 \mathrm{~m}^{2}=10,260 \mathrm{~m}^{2}$

$\Psi_{2} \times A_{2}=0.15 \times 800 \mathrm{~m}^{2}=120 \mathrm{~m}^{2}$

$\Psi_{3} \times A_{3}=0.05 \times 3,100 \mathrm{~m}^{2}=155 \mathrm{~m}^{2}$

$\Sigma A=11,400 m^{2}+800 m^{2}+3,100 m^{2}=15,300 m^{2}$

$=1.53 \mathrm{ha}$

$\Psi_{m}=\left(10,260 \mathrm{~m}^{2}+120 \mathrm{~m}^{2}+155 \mathrm{~m}^{2}\right) / 11,300=0.93$

$Q_{r}=177.1 \mathrm{l} / \mathrm{s} \times 0.93 \times 1.53 \mathrm{ha} \approx 252 \mathrm{l} / \mathrm{s}$

$252 \mathrm{l} / \mathrm{s} \times 15 \mathrm{~min}(900 \mathrm{~s})=226,800 \mathrm{I}=226.8 \mathrm{~m}^{3}$ of water

Therefore, the surface runoff for Grzybowski Square amounts to $226.8 \mathrm{~m}^{3}=226,800 \mathrm{I}$.

The NDVI map for Grzybowski Square in Warsaw (Figure 4) shows the intensity of the photosynthesis process. As can be clearly seen, the white chestnut trees (Aesculus hippocastanum) on the west side in zone A have a reduced NDVI, and the row of Crimean limes (Tilia $x$ euchlora) in zone B are weakened. The analysis shows the negative effect of the difficult urban conditions on the stand, including the reduction in the waterpermeable surface under the trees implemented as part of the competition project in 2008. As a result, the
Crimean lindens suffer from periods of urban drought. The irrigation needs of the 16 Crimean lindens on Grzybowski Square in zone B with an area under the canopy of approximately $350 \mathrm{~m}^{2}$ and a total $\mathrm{DBH}$ of around $465 \mathrm{~cm}$ are as follows:

- 17,500 I of water for a single watering, assuming $50 \mathrm{l} / \mathrm{m}^{2}$ (Bartosiewicz, 1986);

- 4,650 I of water for a single watering, assuming a calculation based on DBH (Bartosiewicz, 1986);

- 12,250 I of water for a single watering of a Crimean lime, according to the index from the Standards (Borowski et al., 2016);

- Assuming a watering model based only on the temperature, the demand of 16 Crimean limes on a day with an average temperature of $21^{\circ} \mathrm{C}$ will be $3.5 \mathrm{~mm}$, which gives circa 12,250 I of water necessary for watering. This calculation was made using the online abacus on the website of the Platform for Supporting Irrigation Decisions (https://geo portal360.pl/map/\#l:52.23589,21.0037,19;p:MTQ 2NTEwXzguMDMwNi40Ny80).

As can be seen, different methods can produce varying results. The lowest water demand index is generated by estimates based on DBH. Calculations based on the temperature model and the Standards (Borowski et al., 2016) are identical and resemble estimates by Bartosiewicz (1986).

Based on the data obtained from calculations based on the Standards (Borowski et al., 2016) and the $12,250-$ I temperature model, the retention capacity of Grzybowski Square can cover 18 waterings per season. Proportionally, all 46 trees (assuming needs of $35 \mathrm{l} / \mathrm{m}^{2}$ ) require an average of $35,220 \mathrm{I}$, which would be satisfied by six waterings from retention water. Considering the need for watering on average once a month (Bartosiewicz, 1986), we can assume that the retained water would ensure the needs of the trees throughout the growing season (in the spring and autumn months rainfall reduces watering needs).

The calculation of water demands from trees in the Old Market, Lodz, is given in Table 6.

The retention capacity in the design proposal for the Old Market Square, assuming generalised data, would

Table 5. Old Market Square, Lodz: Percentage share of different surfaces in the area of the square.

\begin{tabular}{|c|c|c|c|c|c|}
\hline & & 1917 & 1925-1939 & 1956-2020 & Concept Design \\
\hline Paved area: & Pedestrians & $10 \%\left(900 \mathrm{~m}^{2}\right)$ & $40 \%\left(3,600 \mathrm{~m}^{2}\right)$ & $66 \%\left(5,900 \mathrm{~m}^{2}\right)$ & $78 \%\left(7,000 \mathrm{~m}^{2}\right)$ \\
\hline Impervious surface & Traffic & $40 \%\left(3,800 \mathrm{~m}^{2}\right)$ & $28 \%\left(2,700 \mathrm{~m}^{2}\right)$ & $22 \%\left(2,000 \mathrm{~m}^{2}\right)$ & $17 \%\left(1,500 \mathrm{~m}^{2}\right)$ \\
\hline Permeable surfaces & & $50 \%\left(4,600 \mathrm{~m}^{2}\right)$ & & & \\
\hline \multicolumn{2}{|c|}{ Biologically active surface } & & $32 \%\left(3,000 \mathrm{~m}^{2}\right)$ & $12 \%\left(1,100 \mathrm{~m}^{2}\right)$ & $5 \%\left(500 \mathrm{~m}^{2}\right)$ \\
\hline \multicolumn{3}{|l|}{ Water surface } & & & Pavement fountain \\
\hline
\end{tabular}

Notes: Permeable surface, other than biologically active surface, including "threshing floor." All values included in the table are approximate. 

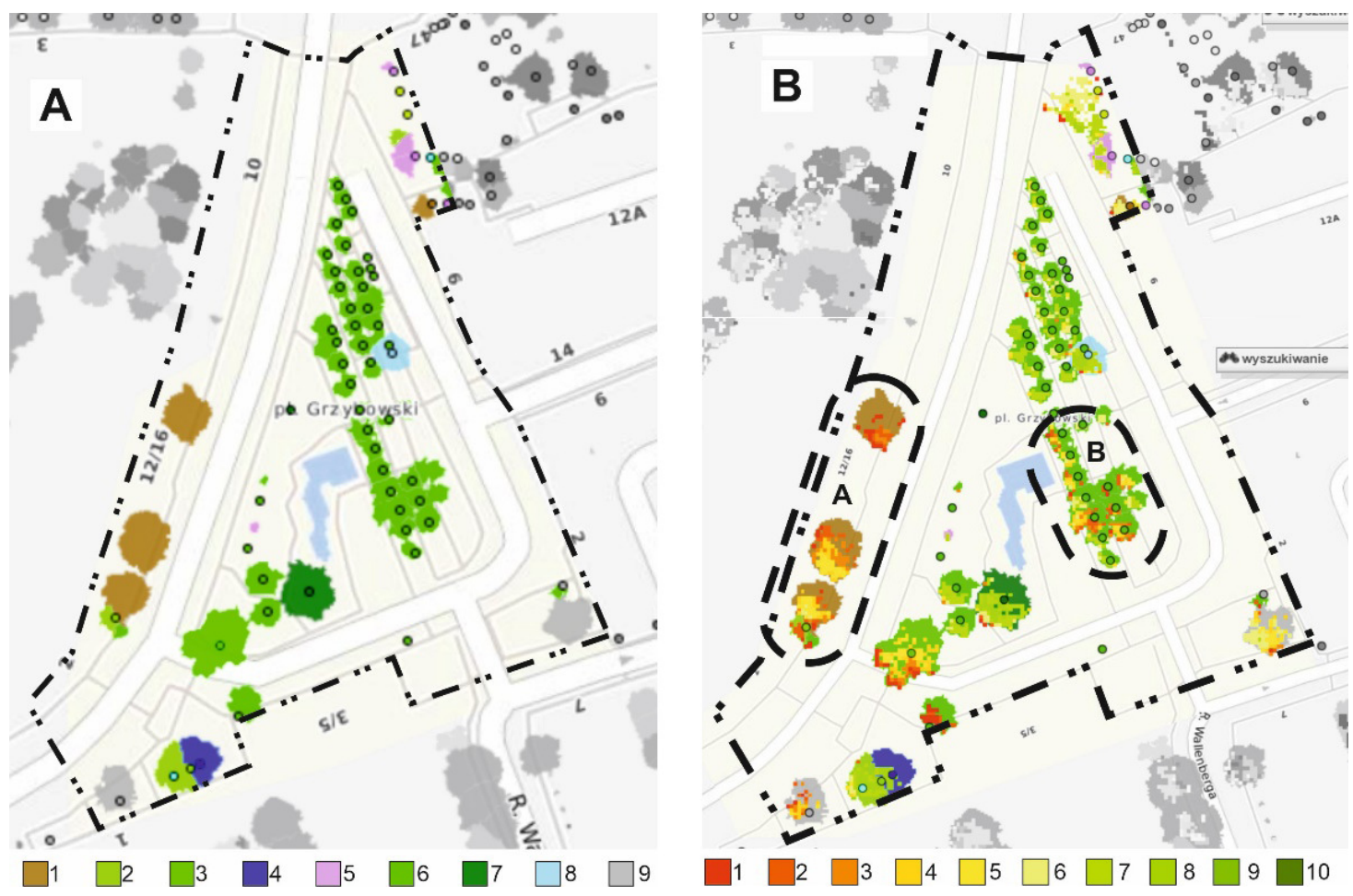

Figure 4. A) Map of tree species and crown cover. Legend: 1. Aesculus sp., 2. Acer sp., 3. Populus sp., 4. Robinia sp., 5. Prunis sp., Malus sp., and Pyrus sp., 6. Tilia sp., 7. Quercus sp., 8. Ulmus sp., 9. Others; B) Map of NDVI for Grzybowski Square in Warsaw. Legend: $1.0 .00-0.50,2.0 .50-0.60,3.0 .60-0.65,4.0 .65-0.70,5.0 .70-0.75,6,0.75-0.80,7.0 .80-0.85$, 8. $0.85-0.90,9.0 .90-0.95 ; 10.0 .95-1.00$. Source: Biuro Geodezji i Katastru (n.d.).

supply six to eight waterings of the trees in the square. In the current state, the surface runoff is smaller and more water is retained. As in the case of Grzybowski Square, the retained water in the Old Market Square can cover watering of trees throughout the growing season. This refers both to the current state and the design proposal. However, the higher share of previous surfaces might enable better conditions for the growth of local vegetation, including trees.

\subsection{Insolation Analyses}

Insolation analyses enabled us to determine the conditions resulting from the shape and dimensions of the urban fabric. The results can inform recommendations for public space design, including $\mathrm{GI}$, minimising the UHI, using solar energy, etc. Model studies were carried out on virtual 3D models of Grzybowski Square in Warsaw and Old Market Square in Lodz and the surrounding areas

Table 6. Old Market Square, Lodz: Calculations of water demand from trees in the current state and in the design proposal.

\begin{tabular}{|c|c|c|}
\hline \multicolumn{3}{|c|}{ Watering Demand From Trees } \\
\hline Method & Current State & Design Proposal \\
\hline $50 \mathrm{l} / \mathrm{m}^{2}$ (Bartosiewicz, 1986) & 12,0001 & 20,0001 \\
\hline Calculations based on DBH (Bartosiewicz, 1986) & 3,4801 & 5,8001 \\
\hline Index based on the Standards (Dworniczak \& Reda, 2019) * & $12,000 \mid$ & 20,0001 \\
\hline $\begin{array}{l}\text { Watering model based on temperature, the demand on a } \\
\text { day with an average temperature of } 21^{\circ} \mathrm{C} \text { will be } 3.5 \mathrm{~mm} * *\end{array}$ & 8,4001 & 14,0001 \\
\hline Surface runoff & 116,0001 & $122,000 ।$ \\
\hline
\end{tabular}

Notes: In the current state there are 12 trees with a crown area of $240 \mathrm{~m}^{2}$ and a total DBH of $348 \mathrm{~cm}$. In the design proposal there are 20 trees (12 existing and eight newly planted). The crown area has been estimated as $400 \mathrm{~m}^{2}$ and DBH as $580 \mathrm{~cm}$. The watering demands refer to one-time spray irrigation. * The indicator from "Standards for shaping greenery in Lodz (project)" (Dworniczak \& Reda, 2019) states that $50 \mathrm{~cm}$ of soil should be irrigated, i.e., the converter value equals $50 \mathrm{l} / \mathrm{m}^{2}$.** Assuming a watering model based solely on temperature, the demand of trees on a day with an average temperature of $21^{\circ} \mathrm{C}$ will be $3.5 \mathrm{~mm}\left(35 \mathrm{I} / \mathrm{m}^{2}\right)$. The calculations were made using the online abacus on the Platform for Supporting Irrigation Decisions (https://geoportal360.pl/map/\#l:52.23589,21.0037,19; p:MTQ2NTEwXzguMDMwNi40Ny80). 
using Archicad software, on dates significant from the point of view of vegetation growth (Figure 5). The insolation was analysed on the days of the equinoxes (March 20 and September 22) and on the longest day of the year (June 21), as these dates show the boundary conditions and significant parameters of insolation.

The analysed area in the Old Market Square in Lodz is well lit by daylight. Its area is dominated by a zone of two to three hours of shade. This creates favourable conditions for the development of vegetation in the square. Significant sunlight raises the risk of an UHI, if fast-heating or dark materials are used. Shaded zones for up to four hours are located on the eastern and western frontages of the square. Significantly shaded zones were not observed.

Most of the Grzybowski Square area is suitable for photophilous plants. In a large area, it is also possible to obtain energy from solar sources. In the designated area, which is also sunny in the autumn and spring, photocatalytic materials can be used to minimise air pollution (smog) in the autumn and winter periods and early spring. The southern frontage of the square is a suitable place for shade plants. The remaining part of the square is suitable from the point of view of insolation for the development of urban vegetation.

\section{Discussion and Recommendations}

In our investigation, we calculated surface runoff, the watering demands of trees, and insolation in urban spaces. The surface runoff combined with the watering needs of urban vegetation makes it possible to define a balanced state when the vegetation requirements are satisfied. Similarly, our study of insolation enables identification of the proper conditions for trees and other species to thrive in urban areas. These features contribute a limited piece to a holistic image of the com- plex nature of urban ecosystems, which can be used to ensure the resilience of urban greening interventions. In particular, the features relate to "nature type 3"functional greening, using the typology introduced by Kowarik (2005). Other elements that should be considered include the temperature regulation, the urban water cycle, air flow regulation, and creating proper outdoor conditions for social activities.

Our survey of the existing methodologies shows that the results of modelling depend strongly on local conditions, in terms of local climate, native species, and the features of the physical environment. The species and local biodiversity further depend on climate change and management processes. For instance, while fertilisers support plant growth and $\mathrm{CO}_{2}$ sequestration, they do not contribute to plant biodiversity (Köhler \& Kaiser, 2021). Under the changing climate conditions in Central European cities, drought-tolerant plants are required. Plants need to be adjusted to future climatic conditions. Köhler and Kaiser (2021) and Liu et al. (2019) recommend prairie plants from North America for Central Europe under drought conditions. Another recommendation is to permit weeds that can withstand extreme drought conditions (Vanstockem et al., 2019) to increase biodiversity and resilience. Capturing morning dew, which works better on horizontal surfaces (pavements, green roofs), can also help ensure water resilience (Heusinger \& Weber, 2015; Köhler \& Kaiser, 2021). Due to the high complexity of the involved phenomena and their interdependencies and local specificity, these topics require further exploration.

The specific parameters of each element in the system depend on the others. For example, trees are more efficient at sequestrating $\mathrm{CO}_{2}$ when they feature higher leaf area index and NDVI values. These parameters, in turn, depend on the conditions of the trees, which depend on proper watering and insolation.
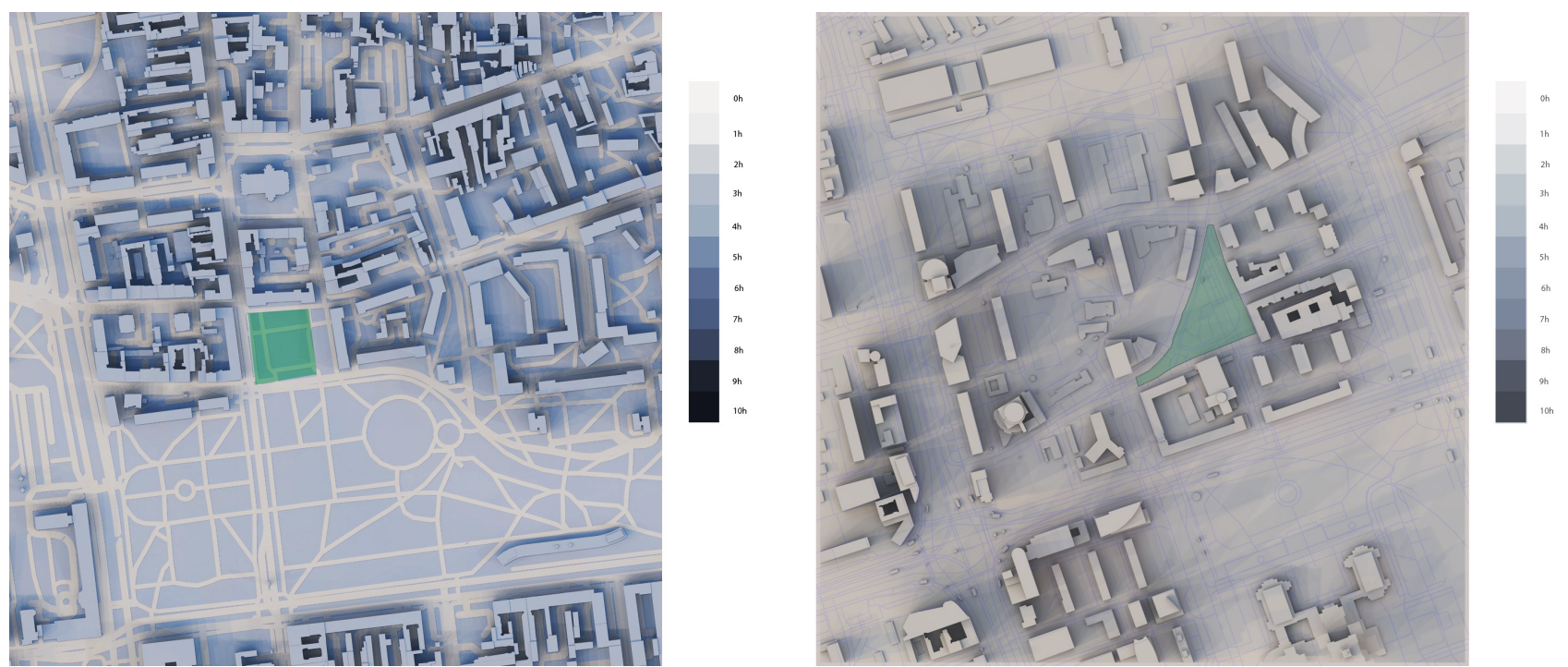

Figure 5. Analyses of the shading of the area and surroundings of Old Market Square in Lodz (left) and Grzybowski Square in Warsaw (right) on March 20, June 21, and September 22. The legend shows the number of hours of shade. 
Our study shows that these requirements might be satisfied by verifying the water and insolation conditions at the design stage. In both squares, we recommend increasing the amount of greenery, including large trees and elements of blue infrastructure, to improve the hygrothermal conditions. Due to the likelihood of high transpiration, we suggest using water-permeable paving materials. To improve the conditions for urban vegetation we recommend limiting the height of buildings surrounding the squares to assure proper insolation and strengthening the connections with the surrounding green areas.

\section{Conclusions and Future Research Pathways}

In this article, our goal was to define a normative framework for urban design integrating urban greenery. The collected parameters related the features of urban vegetation to the physical city fabric. We used regulatory ecosystem services as a reference to evaluate the impact of animate and inanimate elements of the urban environment. We discussed in detail the methodology for assessing some of the parameters for describing those elements. Furthermore, we proposed an assessment of two public spaces, with a focus on the functioning of urban vegetation versus the surrounding environment. The evaluation was based on the balancing of water retention and water demand from trees. It was completed by an analysis of insolation to determine the conditions for urban vegetation growth. Even the limited number of features considered provides some preliminary insights into the complexity of the functioning of the urban ecosystem. Future work should consider other aspects of the urban environment from the social-ecological systems perspective. Additional extensive research is needed to further grasp the complexity of combined green, blue, and grey infrastructure in cities.

\section{Acknowledgments}

We express our thanks to the referees on the initial draft of this article. This research has been funded through the support from the Faculty of Architecture of the Warsaw University of Technology.

\section{Conflict of Interests}

The authors declare no conflict of interests.

\section{References}

Alberti, M. (2008). Advances in urban ecology. Springer. https://doi.org/10.1007/978-0-387-75510-6

Altanzagas, B., Luo, Y., Altansukh, B., Dorjsuren, C., Fang, J., \& Hu, H. (2019). Allometric equations for estimating the above-ground biomass of five forest tree species in Khangai, Mongolia. Forests, 10(8), 1-17.

Andersson, E. (2006). Urban landscapes and sustainable cities. Ecology and Society, 11(1), Article 34. https:// doi.org/10.5751/ES-01639-110134

Andersson, E., Barthel, S., Borgström, S., Colding, J., Elmqvist, T., Folke, C., \& Gren, Å. (2014). Reconnecting cities to the biosphere: Stewardship of green infrastructure and urban ecosystem services. Ambio, 43(4), 445-453. https://doi.org/10.1007/s13280014-0506-y

Andersson, E., Langemeyer, J., Borgström, S., McPhearson, T., Haase, D., Kronenberg, J., Barton, D. N., Davis, M., Naumann, S., Röschel, L., \& Baró, F. (2019). Enabling green and blue infrastructure to improve contributions to human well-being and equity in urban systems. BioScience, 69(7), 566-574. https:// doi.org/10.1093/biosci/biz058

Armson, D., Stringer, P., \& Ennos, A. R. (2012). The effect of tree shade and grass on surface and globe temperatures in an urban area. Urban Forestry and Urban Greening, 11(3), 245-255. https://doi.org/10.1016/ j.ufug.2012.05.002

Badach, J., Dymnicka, M., \& Baranowski, A. (2020). Urban vegetation in air quality management: $A$ review and policy framework. Sustainability, 12(3). https://doi. org/10.3390/su12031258

Bartosiewicz, A. (1986). Urzqdzanie terenów zieleni [Management of green areas]. WSiP.

Barwise, Y., \& Kumar, P. (2020). Designing vegetation barriers for urban air pollution abatement: A practical review for appropriate plant species selection. Npj Climate and Atmospheric Science, 3(1), 1-19. https:// doi.org/10.1038/s41612-020-0115-3

Berkes, F., \& Folke, C. (2000). Linking social and ecological systems for resilience and sustainability. In F. Berkes \& C. Folke (Eds.), Linking social and ecological systems. Management practices and social mechanisms for building resilience (pp. 1-25). Cambridge University Press.

Biuro Geodezji I Katastru. (n.d.). Miasto Stołeczne Warszawa-Warszawa Dzisiaj [City of WarsawWarsaw today]. Mapa Warszawy. http://mapa.um. warszawa.pl/mapaApp1/mapa?service=zielen

Borowski, J., Fortuna-Antoszkiewicz, B., Łukaszkiewicz, J., Rosłoń-Szeryńska, E., Sitarski, M., Suchocka, M., \& Wysocki, C. (2016). Standardy kształtowania zieleni Warszawy [Standards for shaping the greenery of Warsaw]. Polskie Towarzystwo Dendrologiczne. http://zzw.waw.pl/baza-wiedzy/standardyksztaltowania-zieleni-warszawy

Bryant, M. M. (2006). Urban landscape conservation and the role of ecological greenways at local and metropolitan scales. Landscape and Urban Planning, 76(1/4), 23-44. https://doi.org/10.1016/ j.landurbplan.2004.09.029

Caniggia, G., \& Maffei, G. L. (2001). Architectural composition and building typology: Interpreting basic building. Aliena.

Carter, J. G., Cavan, G., Connelly, A., Guy, S., Handley, J., \& Kaźmierczak, A. (2015). Climate change 
and the city: Building capacity for urban adaptation. Progress in Planning, 95, 1-66. https://doi.org/ 10.1016/j.progress.2013.08.001

Chen, L., Liu, C., Zou, R., Yang, M., \& Zhang, Z. (2016). Experimental examination of effectiveness of vegetation as bio-filter of particulate matters in the urban environment. Environmental Pollution, 208, 198-208. https://doi.org/10.1016/j.envpol.2015.09.006

City of Lodz. (2018). Plan adaptacji do zmian klimatu miasta Łodzi do roku 2030 [Plan of adaptation to climate change in the city of Łódź until 2030]. https://bip.uml.lodz.pl/files/bip/public/BIP_AB/ WOSR_klimat_pro_181003.pdf

City of Paris. (2018). Paris climate action plan: Towards a carbon neutral city and $100 \%$ renewable energies. https://cdn.paris.fr/paris/2019/07/24/1a706797 eac9982aec6b767c56449240.pdf

Colding, J., Barthel, S., Bendt, P., Snep, R., van der Knaap, W., \& Ernstson, H. (2013). Urban green commons: Insights on urban common property systems. Global Environmental Change, 23(5), 1039-1051. https:// doi.org/10.1016/j.gloenvcha.2013.05.006

Conzen, M. R. G. (1960). Alnwick, Northumberland: A study in town-plan analysis. Transactions and Papers (Institute of British Geographers), 27, iii, ix-xi, 1, 3-122. https://doi.org/10.2307/621094

Crichton, D., Nicole, F., \& Roaf, S. (2009). Adapting buildings and cities for climate change. Routledge.

Dierkes, C., Kuhlmann, L., Kandasamy, J., \& Angelis, G. (2002). Pollution retention capability and maintenance of permeable pavements. Global Solutions for Urban Drainage, 1-13. https://doi.org/10.1061/ 40644(2002)40

Dreiseitl, H., \& Grau, D. (Eds.). (2009). New waterscapes: Planning, building and designing with water. Birkhauser.

Dworniczak, Ł., \& Reda, P. (Eds.). (2019). Standardy kształtowania zieleni $w$ Łodzi (projekt) [Green shaping standards in Łódź (project)]. Stowarzyszenie Architektury Krajobrazu.

European Commission. (2021). Forging a climateresilient Europe-The new EU strategy on adaptation to climate change (COM/2021/82 final). https:// eur-lex.europa.eu/legal-content/EN/TXT/?uri=COM: 2021:82:FIN

European Environment Agency. (2016). Urban adaptation to climate change in Europe 2016: Transforming cities in a changing climate (EEA Report No. 12/2016). https://www.eea.europa.eu/publications/urbanadaptation-2016

Fernandez, M., Moreno, D., \& Esquivias, P. (2015). Influence of daylight in urban design as a tool towards a more sustainable city. In P. Mercader-Moyano (Ed.), Proceedings of the II International and IV National Congress on Sustainable Construction and Eco-Efficient Solutions (pp. 1091-1100). University of Seville.

Filho, W. L. (2015). Handbook of climate change adapta- tion. Springer.

Forman, R. T. T., \& Godron, M. (1986). Landscape ecology. Wiley.

Gaj, K. (2012). Carbon dioxide sequestration by Polish forest ecosystems. Forest Research Papers, 73(1), 17-21.

Geiger, W. F., Dreiseitl, H., \& Stemplewski, J. (2010). Neue Wege für das Regenwasser: Handbuch zum Rückhalt und zur Versickerung von Regenwasser in Baugebieten [New ways for rainwater: Handbook on the retention and infiltration of rainwater in building areas]. Division Deutscher Industrieverlag.

Geiger, W., \& Dreiseitl, H. (1999). Nowe sposoby odprowadzania wód deszczowych. Poradnik [New ways of draining rainwater. Guide]. Proj-przem-EKO.

Gill, S. E., Handley, J. F., Ennos, A. R., \& Pauleit, S. (2007). Adapting cities for climate change: The role of the green infrastructure. Built Environment, 33(1), 115-133. https://doi.org/10.2148/benv.33.1.115

Gong, P., Xu, H., Wang, C., Chen, Y., Guo, L., \& Wang, X. (2021). Persistent organic pollutant cycling in forests. Nature Reviews Earth \& Environment, 2(3), 182-197. https://doi.org/10.1038/s43017-020-00137-5

Gustafsson, L., Bauhus, J., Asbeck, T., Augustynczik, A. L. D., Basile, M., Frey, J., Gutzat, F., Hanewinkel, M., Helbach, J., Jonker, M., Knuff, A., Messier, C., Penner, J., Pyttel, P., Reif, A., Storch, F., Winiger, N., Winkel, G., Yousefpour, R., \& Storch, I. (2020). Retention as an integrated biodiversity conservation approach for continuous-cover forestry in Europe. Ambio, 49(1), 85-97. https://doi.org/10.1007/s13280-01901190-1

Haase, D., Schwarz, N., Strohbach, M., Kroll, F., \& Seppelt, R. (2012). Synergies, trade-offs, and losses of ecosystem services in urban regions: An integrated multiscale framework applied to the Leipzig-Halle region, Germany. Ecology and Society, 17(3), Article 22. https://doi.org/10.5751/ES-04853-170322

Hale, J., Pugh, T., Sadler, J., Boyko, C., Brown, J., Caputo, S., Caserio, M., Coles, R., Farmani, R., Hales, C., Horsey, R., Hunt, D., Leach, J., Rogers, C., \& MacKenzie, A. (2015). Delivering a multi-functional and resilient urban forest. Sustainability, 7(4), 4600-4624. https://doi.org/10.3390/su7044600

Hegger, M., Fuchs, M., Stark, T., \& Zeumer, M. (2008). Energy manual sustainable architecture. Brickhauser.

Heusinger, J., \& Weber, S. (2015). Comparative microclimate and dewfall measurements at an urban green roof versus bitumen roof. Building and Environment, 92, 713-723. https://doi.org/10.1016/ j.buildenv.2015.06.002

Jalolen, J., Järvelä, J., \& Aberle, J. (2013). Leaf area index as vegetation density measure for hydraulic analyses. Journal of Hydraulic Engineering, 139(5), 461-469.

Janhäll, S. (2015). Review on urban vegetation and particle air pollution-Deposition and dispersion. Atmospheric Environment, 105, 130-137. https://doi.org/ 10.1016/j.atmosenv.2015.01.052 
Jones, S. (2017). Cities responding to climate change. Palgrave Macmillan.

Kannamma, D., \& Sundaram, A. M. (2015). Empirical study on the interaction between vegetation and street geometry elements towards ambient urban microclimate. Indian Concrete Journal, 89(7), 20-27.

Kassenberg, A., Szymalski, W., Drogosz, L., Bugaj, M., \& Jakubczak, I. (2019). The climate change adaptation strategy for the city of Warsaw by 2030 with the prospects until 2050. Urban adaptation plan. Office of the Capital City of Warsaw. http://adaptcity.pl/wpcontent/uploads/2019/11/strategia_2030-ENG.pdf

Köhler, M., \& Kaiser, D. (2019). Evidence of the climate mitigation effect of green roofs-A 20-year weather study on an extensive green roof (EGR) in Northeast Germany. Buildings, 9(7), Article 157. https:// doi.org/10.3390/buildings9070157

Köhler, M., \& Kaiser, D. (2021). Green roof enhancement on buildings of the university of applied sciences in Neubrandenburg (Germany) in times of climate change. Atmosphere, 12(3), Article 382. https:// doi.org/10.3390/atmos12030382

Körner, C. (2000). Biosphere responses to $\mathrm{CO}_{2}$ enrichment. Ecological Applications, 10(6), 1590-1619. https://doi.org/10.2307/2641226

Košir, M. (2019). Climate adaptability of buildings bioclimatic design in the light of climate change. Springer.

Kowarik, I. (2005). Wild urban woodlands: Towards a conceptual framework. In I. Kowarik \& S. Körner (Eds.), Wild urban woodlands (pp. 1-32). Springer. https:// doi.org/10.1007/3-540-26859-6_1

Kruk, H. (2014). Przegląd wybranych metod oceny bioróżnorodności [Review of selected methods of biodiversity assessment]. Ekonomia i Środowisko, 2(49), 44-62.

Law, N., \& Hanson, J. (2016). Recommendations of the expert panel to define BMP effectiveness for urban tree canopy expansion. Center for Watershed Protection and Chesapeake Stormwater Network. https:// owl.cwp.org/mdocs-posts/recommendations-ofthe-expert-panel-to-define-bmp-effectiveness-forurban-tree-canopy-expansion

Liu, J., Shrestha, P., Skabelund, L. R., Todd, T., Decker, A., \& Kirkham, M. B. (2019). Growth of prairie plants and sedums in different substrates on an experimental green roof in Mid-Continental USA. Science of The Total Environment, 697, Article 134089. https://doi. org/10.1016/j.scitotenv.2019.134089

Liu, O. Y., \& Russo, A. (2021). Assessing the contribution of urban green spaces in green infrastructure strategy planning for urban ecosystem conditions and services. Sustainable Cities and Society, 68, Article 102772. https://doi.org/10.1016/j.scs.2021. 102772

Loughner, C. P., Allen, D. J., Zhang, D. L., Pickering, K. E., Dickerson, R. R., \& Landry, L. (2012). Roles of urban tree canopy and buildings in urban heat island effects: Parameterization and preliminary results.
Journal of Applied Meteorology and Climatology, 51(10), 1775-1793. https://doi.org/10.1175/JAMCD-11-0228.1

Marcus, L., Pont, M. B., \& Barthel, S. (2019). Towards a socio-ecological spatial morphology: Integrating elements of urban morphology and landscape ecology. Urban Morphology, 23(2), 115-124.

Mayor of London. (2018). London Environment Strategy. Greater London Authority. https://www.london.gov. uk/what-we-do/environment/london-environmentstrategy

McDonald, A. G., Bealey, W. J., Fowler, D., Dragosits, U., Skiba, U., Smith, R. I., Donovan, R. G., Brett, H. E., Hewitt, C. N., \& Nemitz, E. (2007). Quantifying the effect of urban tree planting on concentrations and depositions of PM10 in two UK conurbations. Atmospheric Environment, 41(38), 8455-8467. https://doi. org/10.1016/j.atmosenv.2007.07.025

Millennium Ecosystem Assessment. (2005). Ecosystems and human well-being: Biodiversity synthesis. World Resources Institute.

Moser, A., Rahman, M. A., Pretzsch, H., Pauleit, S., \& Rötzer, T. (2017). Inter- and intra-annual growth patterns of urban small-leaved lime (Tilia cordata mill.) at two public squares with contrasting microclimatic conditions. International Journal of Biometeorology, 61(6), 1095-1107.

Myint, S. W., Zheng, B., Talen, E., Fan, C., Kaplan, S., Middel, A., Smith, M., Huang, H., \& Brazel, A. (2015). Does the spatial arrangement of urban landscape matter? Examples of urban warming and cooling in Phoenix and Las Vegas. Ecosystem Health and Sustainability, 1(4), 1-15. https://doi.org/10.1890/EHS14-0028.1

Nakamura, A., Kitching, R. L., Cao, M., Creedy, T. J., Fayle, T. M., Freiberg, M., Hewitt, C. N., Itioka, T., Koh, L. P., Ma, K., Malhi, Y., Mitchell, A., Novotny, V., Ozanne, C. M. P., Song, L., Wang, H., \& Ashton, L. A. (2017). Forests and their canopies: Achievements and horizons in canopy science. Trends in Ecology and Evolution, 32(6), 438-451. https://doi.org/10.1016/j.tree. 2017.02.020

Nascimento, S. M. d. S. G., Souza, A. P. d., Lima, V. L. A. d., Nascimento, C. W. A. d., \& Nascimento, J. J. V. R. d. (2016). Phytoextractor potential of cultivated species in industrial area contaminated by lead. Revista Brasileira de Ciência do Solo, 40, Article e0140805. https://doi.org/10.1590/18069657rbcs20140805

Naumann, S., Davis, M., Iwaszuk, E., Freundt, M., \& Mederake, L. (2020). Addressing climate change in cities-Policy instruments to promote urban naturebased solutions. Ecologic Institute and Sendzimir Foundation.

Niemelä, J., Saarela, S. R., Söderman, T., Kopperoinen, L., Yli-Pelkonen, V., Väre, S., \& Kotze, D. J. (2010). Using the ecosystem services approach for better planning and conservation of urban green spaces: A Finland case study. Biodiversity and Conservation, 19(11), 3225-3243. https://doi.org/10.1007/ 
s10531-010-9888-8

Norton, B. A., Coutts, A. M., Livesley, S. J., Harris, R. J., Hunter, A. M., \& Williams, N. S. G. (2015). Planning for cooler cities: A framework to prioritise green infrastructure to mitigate high temperatures in urban landscapes. Landscape and Urban Planning, 134, 127-138.

Nowak, D. J. (2002). The effect of urban trees on air quality. USDA Forest Service, Northern Research Station, Syracuse, NY.

Nowak, D. J., Greenfield, E. J., Hoehn, R. E., \& Lapoint, E. (2013). Carbon storage and sequestration by trees in urban and community areas of the United States. Environmental Pollution, 178, 229-236.

Nowak, D. J., Hoehn, R., \& Crane, D. E. (2007). Oxygen production by urban trees in the United States. Arboriculture \& Urban Forestry, 33(3), 220-226.

Nowak, D. J., Rowntree, R. A., McPherson, E. G., Sisinni, S. M., Kerkmann, E. R., \& Stevens, J. C. (1996). Measuring and analyzing urban tree cover. Landscape and Urban Planning, 36(1), 49-57.

Oliveira, V. (2016). Urban morphology: An introduction to the study of the physical form of cities. Springer.

Oliver, T. H., Heard, M. S., Isaac, N. J. B., Roy, D. B., Procter, D., Eigenbrod, F., Freckleton, R., Hector, A., Orme, C. D. L., Petchey, O. L., Proença, V., Raffaelli, D., Suttle, K. B., Mace, G. M., Martín-López, B., Woodcock, B. A., \& Bullock, J. M. (2015). Biodiversity and resilience of ecosystem functions. Trends in Ecology and Evolution, 30(11), 673-684. https://doi.org/ 10.1016/j.tree.2015.08.009

Pace, R., De Fino, F., Rahman, M. A., Pauleit, S., Nowak, D. J., \& Grote, R. (2021). A single tree model to consistently simulate cooling, shading, and pollution uptake of urban trees. International Journal of Biometeorology, 65(2), 277-289. https://doi.org/10.1007/ s00484-020-02030-8

Peper, P., McPherson, E. G., Simpson, J. R., Gardner, S., Vargas, K., \& Xiao, Q. (2007). New York City, New York municipal forest resource analysis. U.S. Department of Agriculture Forest Service, Pacific Southwest Research Station, Center for Urban Forest Research.

Pérez-Suárez, M., Fenn, M. E., Cetina-Alcalá, V. M., \& Aldrete, A. (2008). The effects of canopy cover on throughfall and soil chemistry in two forest sites in the México City air basin. Atmosfera, 21(1), 83-100.

Piotrowska-Niczyporuk, A., \& Bajguz, A. (2013). Fitoremediacja - alternatywa na czyste środowisko [Phytoremediation - An alternative for a clean environment]. In I. Ciereszko \& A. Bajguz (Eds.), Różnorodność biologiczna ekosystemu. Rośliny i grzyby w zmieniajacych się warunkach środowiska [Ecosystem biodiversity. Plants and fungi under changing environmental conditions] (pp. 97-110). Polskie Towarzystwo Botaniczne.

Popek, R. (2013). Ocena zdolności wybranych gatunków drzew i krzewów w fitoremediacji mikropyłów z powietrza $w$ terenie zurbanizowanym [Estimation of the ability of selected tree and shrub species to phytoremediate particulate matter in urban areas] [Unpublished doctoral dissertation]. Warsaw University of Life Sciences.

Redman, C. L., Grove, J. M., \& Kuby, L. H. (2004). Integrating social science into the long-term ecological research (LTER) network: Social dimensions of ecological change and ecological dimensions of social change. Ecosystems, 7(2), 161-171. https://doi.org/ 10.1007/s10021-003-0215-z

RetencjaPL. (2020). Polski Atlas Natężeń Deszczów (PANDa) [The Polish Rain Intensity Atlas (PANDa)]. PANDa. https://atlaspanda.pl/o-projekcie

Reusswig, F., Becker, C., Lass, W., Haag, L., \& Hirschfeld, J. (2016). Adapting to the impacts of climate change in Berlin (AFOK): Executive summary. Berlin Senate Department for the Environment, Transport and Climate Protection.

Rowntree, R. A., \& Nowak, D. J. (1991). Quantifying the role of urban forests in removing atmospheric carbon dioxide. Journal of Arboriculture, 17(10), 269-275.

Saratsis, E., Dogan, T., \& Reinhart, C. F. (2017). Simulation-based daylighting analysis procedure for developing urban zoning rules. Building Research \& Information, 45, 478-491.

Schirru, M., Canu, S., Santona, L., Lai, S., \& Motroni, A. (2019). From ecosystems to ecosystem services: A spatial methodology applied to a case study in Sardinia. In C. Gargiulo \& C. Zoppi (Eds.), Planning, nature and ecosystem services (pp. 130-141). Federico II Open Access University Press.

Shashua-Bar, L., \& Hoffman, M. E. (2003). Geometry and orientation aspects in passive cooling of canyon streets with trees. Energy and Buildings, 35(1), 61-68. https://doi.org/10.1016/S0378-7788(02)00080-4

Simic, A., Fernandes, R., \& Wang, S. (2004). Sensitivity assessment of simulated evapotranspiration and groundwater recharge across a shallow water region for diverse land cover and soil properties. In International Geoscience and Remote Sensing Symposium (Vol. 7, pp. 4881-4884). IEEE.

Stewart, I. D., \& Oke, T. R. (2012). Local climate zones for urban temperature studies. Bulletin of the American Meteorological Society, 93, 1879-1900.

Szczepanowska, H. B., \& Sitarski, M. (2015). Drzewa zielony kapitał miast. Jak zwiększyć efektywność pracy drzew? [Green trees in the capital of cities. How to increase the efficiency of trees' work?]. Instytut Gospodarki Przestrzennej i Mieszkalnictwa.

Vanstockem, J., Somers, B., \& Hermy, M. (2019). Weeds and gaps on extensive green roofs: Ecological insights and recommendations for design and maintenance. Urban Forestry \& Urban Greening, 46, Article 126484. https://doi.org/10.1016/j.ufug.2019.126484

Wei, X., Lyu, S., Yu, Y., Wang, Z., Liu, H., Pan, D., \& Chen, J. (2017). Phylloremediation of air pollutants: Exploiting the potential of plant leaves and leafassociated microbes. Frontiers in Plant Science, 8(2), 
1-23. https://doi.org/10.3389/fpls.2017.01318

Whitford, V., Ennos, A. R., \& Handley, J. F. (2001). "City form and natural process" - Indicators for the ecological performance of urban areas and their application to Merseyside, UK. Landscape and Urban Planning, 57(2), 91-103. https://doi.org/10.1016/S01692046(01)00192-X

Wu, J., \& Liang, S. (2020). Assessing terrestrial ecosystem resilience using satellite leaf area index. Remote Sensing, 12(4), 1-20. https://doi.org/10.3390/ rs12040595

Yang, B., Lee, D. K., Heo, H. K., \& Biging, G. (2019). The effects of tree characteristics on rainfall interception in urban areas. Landscape and Ecological Engineering, 15(3), 289-296. https://doi.org/10.1007/ s11355-019-00383-w

Zasada, M., Bronisz, K., Bijak, S., Wojtan, R., Tomusiak,
R., Dudek, A., Michalak, K., \& Wróblewski, L. (2008). Wzory empiryczne do określania suchej biomasy nadziemnej części drzew i ich komponentów [Empirical formulae for determination of the dry biomass of aboveground parts of the tree]. Sylwan, 152(3), 27-39.

Zianis, D., Muukkonen, P., Mäkipää, R., \& Mencuccini, M. (2005). Biomass and stem volume equations for tree species in Europe (Silva Fennica Monographs, Vol. 4). The Finnish Society of Forest Science.

Ziter, C. D., Pedersen, E. J., Kucharik, C. J., \& Turner, M. G. (2019). Scale-dependent interactions between tree canopy cover and impervious surfaces reduce daytime urban heat during summer. Proceedings of the National Academy of Sciences of the United States of America, 116(15), 7575-7580. https://doi.org/ 10.1073/pnas.1817561116

\section{About the Authors}

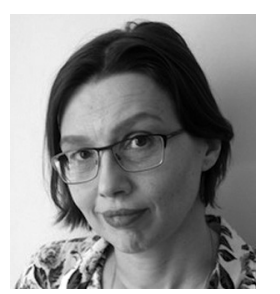

Małgorzata Hanzl is an associate professor at Lodz University of Technology and lecturer at the Faculty of Architecture, Warsaw University of Technology where she received her PhD. She is a vice president of ISUF Polska and part of the Urban Morphology Editorial Board. She received a Fulbright Scholarship as a visiting researcher in SENSEable City Laboratory, MIT, and was active in the International Society of City and Regional Planners (ISOCARP) as part of board of directors. She has got extensive experience as a planning practitioner.

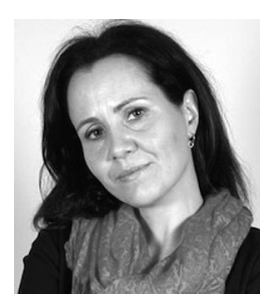

Anna Tofiluk is assistant professor at the Faculty of Architecture of the Warsaw University of Technology. She graduated from the Wroclaw University of Science and Technology. Her interests include sustainable architecture and urbanism, built environment and climate change, building materials and technologies with a focus on prefabrication, and technical and freehand drawing. She is also the author of technical drawing textbook, articles, and chapters in multi-author books, one of the supervisors of the Faculty of Architecture's students' scientific society of climate crisis architecture, and a member of the Association of Polish Architects.

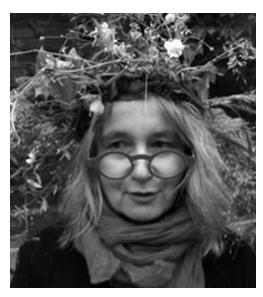

Kinga Zinowiec-Cieplik is a landscape architect who graduated from the Warsaw University of Life Sciences' Faculty of Horticulture and a post-graduate alumna of the École Nationale Supérieure du Paysage de Versailles, France. She specialises in designing recreational spaces with a focus on social and natural values. She has designed parks and public squares and has published on pro-environmental design. She is also member of the Association of Polish Architects, a working group of sustainable architecture, the Association of Polish Landscape Architects, and the Association of Horticultural Engineers and Technicians.

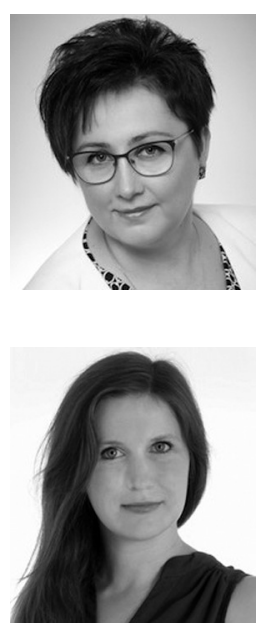

Magdalena Grochulska-Salak is assistant professor at the Faculty of Architecture of the University of Technology and at the Department of Civil Engineering of the Warsaw University of Life Science, as well as an academic lecturer, researcher, author, and reviewer of scientific publications. She is a member of interdisciplinary scientific and expert teams. Her main scientific interests are sustainable development and urban resilience. She has served as an advisor in investment processes and project manager and consultant on sustainable development and climate change adaptation. She is also a member of the Scientific Society for Revitalization and the Association of Polish Architects.

Anna Nowak is assistant professor at the Faculty of Architecture of the Warsaw University of Technology. Her interests and research work cover the field of bionics in architecture, minimization of material consumption, interdisciplinary design, modern material solutions, and building technologies. She received an award from the Polish Minister of Development for best PhD dissertation. 